\title{
Deliverance of Women and Rabindranath Tagore: In Vista of Education
}

\author{
Dr. Tapas Pal and Dr. Sanat Kumar Rath
}

\begin{abstract}
Gurudevas role in the liberation of women was a determining one. He uncovered the dilemma of women and argued for their independence through his letters, short stories, and essays. Through his novels, he was able to construct new and vital female role models to motivate a new generation of Bengali women. Later, by his act of admitting females into his Santiniketan Ashram education, he became an innovative pioneer in coeducation.
\end{abstract}

Keywords--- Liberation of Women, Ashram Education

\section{INTRODUCTION}

G URUDEVA'S role in the liberation of women was a Jdetermining one. He uncovered the dilemma of women and argued for their independence through his letters, short stories, and essays. Through his novels, he was able to construct new and vital female role models to motivate a new generation of Bengali women. Later, by his act of admitting females into his Santiniketan Ashram education, he became an innovative pioneer in coeducation.

\section{OBJECTIVES}

To illustrate the Rabindranath Tagore's educational works for liberation of women.

\section{MEthodology}

It is completely based on literature review from Tagore's letters, short stories, essays, and different photographs of Santiniketan.

\section{Result AND Discussion}

Novel Gora

The population of this novel Gora was important for its delineation of young female characters and the manner in which they interacted with the society around them. Such characters as Lolita, Sucharita and Anandamayee are shown in the process of shaping new identities and personal autonomy as they develop exchange ways of interaction with men and society.

\section{Essay 'Strisliksha'}

His essay 'Strisliksha' (female education), which was initially published in the journal Sabuj Patra and later translated as 'The education of women's in August 1915, states in no uncertain terms that there should be equality in education. "Whatever is worth knowing is knowledge. It should be known equally by men and women not for the sake of practical utility, but for the sake of knowing the desire to know is the law of human nature.(Shiksha, vol.1).

\section{Extra-curricular Activities such as the 1910 Drama Lakshmir Puja}

As Santiniketan expanded to include women as students and village welfare as objectives, curriculum innovations were required. These often took place through extra-curricular activities such as the 1910 drama Lakshmir puja, which was staged and performed by female students. Tagore brought in dance teacher from Banaras to train the girls and when they left, he personally taught them.

\section{'Nari-Bhavana'}

With the foundation of Visva-Bharati, a residence known as 'Nari-Bhavana' began attracting female students from India and abroad. The girls participated in all the academic departments with virtually the same courses as the male students.

\section{Class of American nurse- Gretchen Green}

In addition, they also receive the special classes in cooking and kitchen work from an American nurse, Gretchen Green, who was attached to Sriniketan.

\section{Social and Cultural Activities}

Along with the general social and cultural activities of the institution, the girls organized their own clubs, societies and organizations.

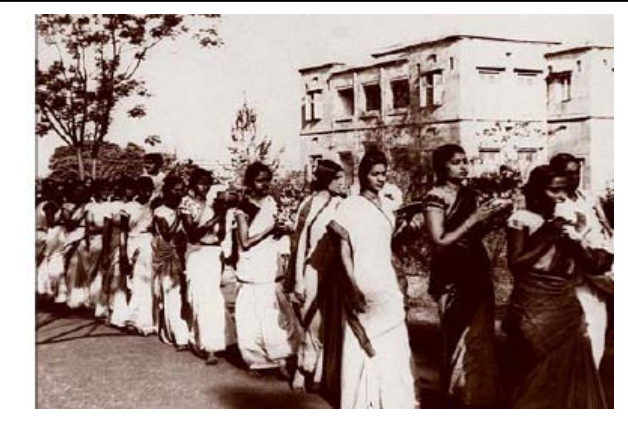

A ceremonial procession at Santiniketan. Indira Gandhi is seen (fourth from right) as a student of Visva-Bharati during 1934-35:the view of Women participation. 


\section{Physical Education}

Rabindranath believed in a holistic education, and the girls were encouraged to participate in physical education as well. They engaged in games, sports, hikes and excursion, and ever the athletics of self-defence such as lathi play and ju-jitsu.

\section{Brati- Balikas}

In Sriniketan, Dhirananda Roy (1902-1971), a former student, organised the Brati-Balakas/ Brati- Balikas (literally boys and girls cuho have taken a vow), a group patterned after the boy scouts/ girls guides and American 4-H movement.

\section{Ghare Baire}

The female characters are captured mostly in a crisis moment, in a critical situation of their life and none of them are as highly educated as their male counterparts. For example, though Bimala in Ghare Baire takes part in the Nationalist movements, her sexual identity becomes prominent till the end.

\section{Chokher Bali}

In Chokher Bali, though Binodini appears to be an intellectual and well-mannered woman at the beginning, the repressed sexual desire of the young wide gets so clearly expressed that it main all other aspects of her character.

\section{Short Story "The Conclusion"}

In his short story "The Conclusion” there is a portrayal of a reckless and radical womanhood.

\section{Story Mrinmaui}

This emphasis that literacy for women is of little importance in a society where their roles as male caretakers, wife, or mother take precedence. The character of the story Mrinmaui is described as a tomboy who keeps the women of their village " in a constant state of alarm" because she is not in the least interest in behaving like a proper Indian women nor is she troubled that she remains single when most Indian girls of her age have entered into arranged marriage. Mrinmayi has no formal education and ultimately in the story, she is forced into arranged marriages. Even after marriage she is unwilling to mould herself in the desired role of a wife. But ultimately, this 'run away' bride comes back to her husband and succumbs to the role of a wife.

\section{Short Story Laboratory}

Here he had written a few months before his death shows a new woman of that time. Overall, three aspects of women's life-relationship between men and women, their social oppression, and the avatar of a new woman who is confident and makes her own decisions have been depicted by Tagore. In a short story, Laboratory (1940), a mother, Sohini, and her daughter, Nila, flout conventions and values. The promiscuous daughter never achieves her mother's level of social consciousness which leads her to violate traditional values for the sake of science.

\section{Short Story Beggar Girl, Novel Chaturanga, Novel Jogajog, Chandalika and Shyama}

His first short story on women was Beggar Girl (1877). This was the name of the female character in Tagore's 1916 novel Chaturanga. His novel Jogajog accentuates the issue of marital rape. Tagore's other writings, like Chandalika and Shyama, also revolve around female characters.

\section{Co-education in Asham}

Tagore also put down the foundation of co-education by starting it at Santiniketan.

\section{Speech on his Second Visit to America (September 1916 to January 1917)}

In the course of a speech he delivered while he was on his second visit to America (September 1916 to January 1917), Rabindranath Tagore said that a daughter finds herself in the centre of her own true world, the world of human relationship from the moment she is in her mother's arms after birth.

\section{Widow Binodini}

In the novels of Tagore widows are carefully presented. They serve the two-fold purpose of expressing the conflict both within Bengali society and within the women themselves. The widow, Binodini, struggles with her own zeal and unfulfilled love.

\section{Story the Postmaster}

In addition to his remarkable stories about young girls (of which "The Postmaster" is a master piece), Tagore's short stories can be seen as representing three facets of women's lives: i) the romance between men and women, ii) social oppression of women (brilliantly portrayed in stories like "Haimanti") and iii) the birth of the "new woman" - that is, a woman who challenges convention and seeks to make decisions about her own life.

Stories; Anandamoyee in Gora, Jatin's aunt in Shesher Ratri (The Last Night) and Rasmoni in Rasmonir Chhele (Rasmoni's Son)

As a lover and a mother: In Rabindranath's early thinking, women had two principal roles - mother and lover (Pal, Vol. 5: 237). The loving nature of mother has been portrayed in many of his stories; Anan damoyee in Gora, Jatin's aunt in "Shesher Ratri" (The Last Night) and Rasmoni in "Rasmonir Chhele" (Rasmoni's Son) are a few examples. The period during which a writer is born gets reflected through his writings, may be, for a purpose.... The writer's period plays a role, deliberately or otherwise, in a writer's mind. (Mukhopadhyay, Vol.2: 546).

Poems like Marichika (Kori o Komol), Sadharan Meye(Punashcha), Narir Ukti, Byakto Prem, Opekkha, Surdaser Prarthona (all from Manasi)

His poems like Marichika (Kori o Komol), Sadharan Meye(Punashcha), Narir Ukti, Byakto Prem, Opekkha, Surdaser Prarthona (all from Manasi), depicted feminine notes of different issues. From women empowerment to psychological complications to urge for physical beauty 
everything was reflected in these poems of Tagore. Marichika talks about the need of self sufficiency, independence and the need of strong mind to overcome traumas of livelihood among women.

\section{Sonar Tori and Chitra}

In Sonar Tori and Chitra romanticism dominates, and the beautiful woman finds her ultimate expression in the poem "Urvashi":"For ages you have been the world"s lover, Oh you, Urvashiof unparalleled beauty”. Complicated relationships between men and women were portrayed in stories like The Postmaster. The social oppression of women was brilliantly portrayed in stories like Haimanti and Jibito o Mrito. At lastTagore found his modern lady, a woman who challenges convention and seeks to make decisions about her own. All of these were efforts of Rabindranath Tagore to create awareness about social reform concerning women.

\section{Gnanadanandini became a Role Model}

The Tagore family played a seminal role in almost all the innovative socio-cultural changes that occurred in 19th century Bengal, and female liberation was no exception. Most notable was the liberating role of Rabindranath's brother, Satyendranath (1842-1923), whose wife Gnanadanandini (1851-1941) became a role model for modern female behavior. Not only did Gnanadanandini redecorate Bengali female dress to make it more appropriate for travelling beyond the antahpur (inner courtyard) she contributed articles on female educational and social reform to several journals and travelled to England with her three children without the accompaniment of her husband.

\section{Rabindranath's First Trip to England and Bengali Women's Independence}

Rabindranath made his first trip to England in 1878, at the age of 17 , and some of his earliest statements regarding the need for Bengali women's independence come in a series of letters written to his family. After attending a party where British men and women mixed freely, Tagore wrote a letter contrasting the free mixing that occurred between men and women in England and the isolation of Bengali women, who were confined to purdah and separated from the outside world. Wrote Rabindranath: It is only natural that men and women should seek amusement together. Women are a part of the human race and God has created them as part of society. To consider the enjoyment of free mixing between people to be a cardinal sin, to be unsociable and to turn it into a sensational matter is not only abnormal, it is unsocial, and therefore in a sense uncivilized. Men are engrossed in all manner of amusement in the outside world, while women are like their privately owned tamed animals, chained docilely to the walls of the innermost chambers of the houses. (Rabindranath Tagore, Letters froma Sojourner in Europe, ed. Supriya Roy, Visva-Bharati, 2008: 88).

\section{Ratan in the 'Postmaster', Uma in Khata and Kusum in 'Ghater Katha':}

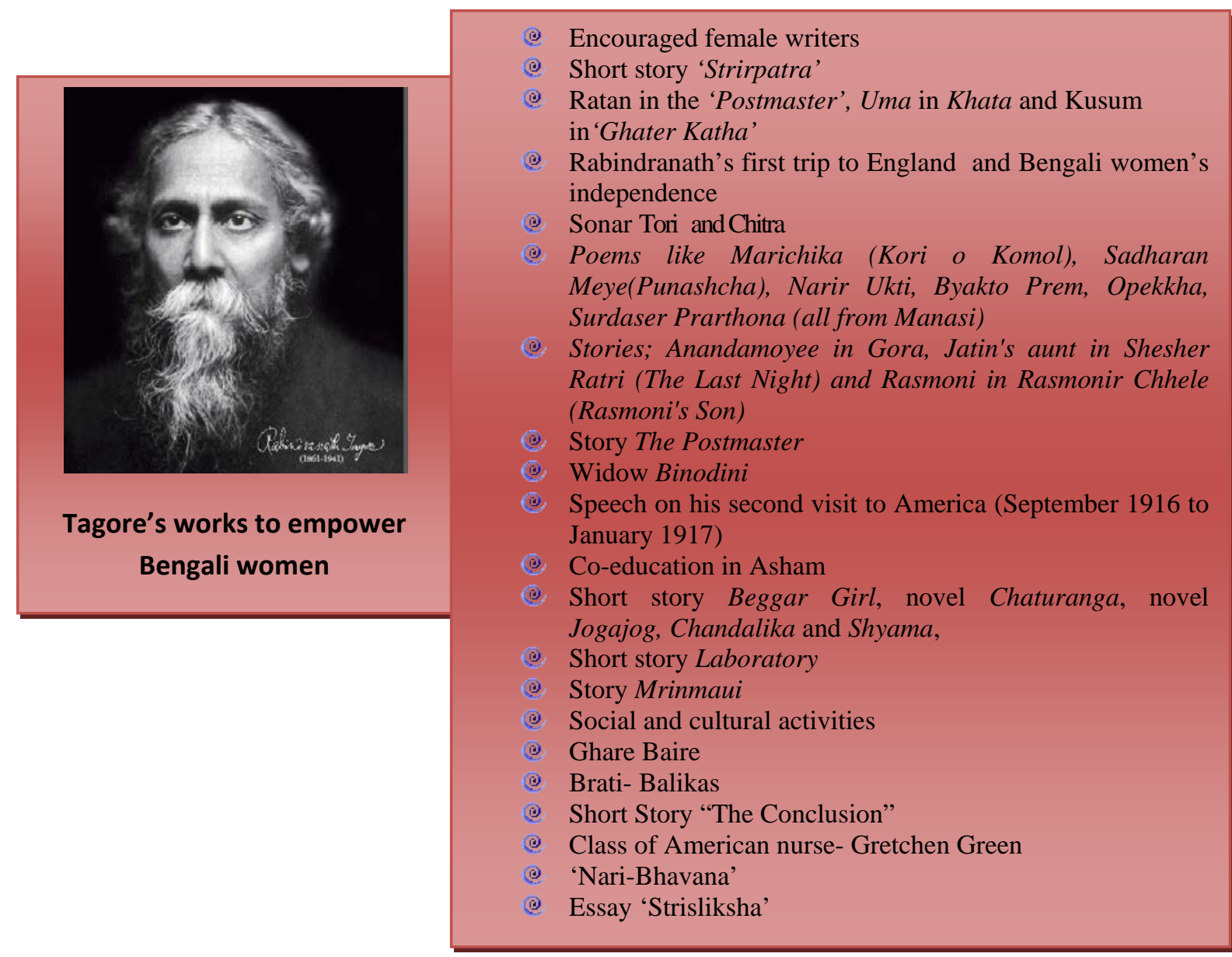


His short stories were written and we find him portraying the plight of orphans and widows such as Ratan in the 'Postmaster' and Kusum in 'Ghater Katha' ('The Tale of the Ghat') or the abuses of the dowry system and child-wives as illustrated by the abuse of Nirupama in 'Dena Paona' ('Profi $t$ and Loss'), as well as the repression of female learning portrayed through the character of Uma in Khata ('Exercise Book').

\section{Short Story 'Strirpatra'}

Rabindranath's most radical short story 'Strirpatra' ('A Wife's Letter') came later. Here the transformation of its main female character Mrinal - an upper caste woman - is portrayed, from submissive wife to autonomous individual. Mrinal chooses to live apart from the joint family as a result of the oppressiveness to a female relative that she witnessed within the family.

\section{Encouraged Female Writers}

It should be noted that Rabindranath also encouraged female writers, and as a result of his encouragement, the feminist writings of Sarat Kumari Chaudhurani (1861-1920) were published in such journals as Sadhana and Bharati.
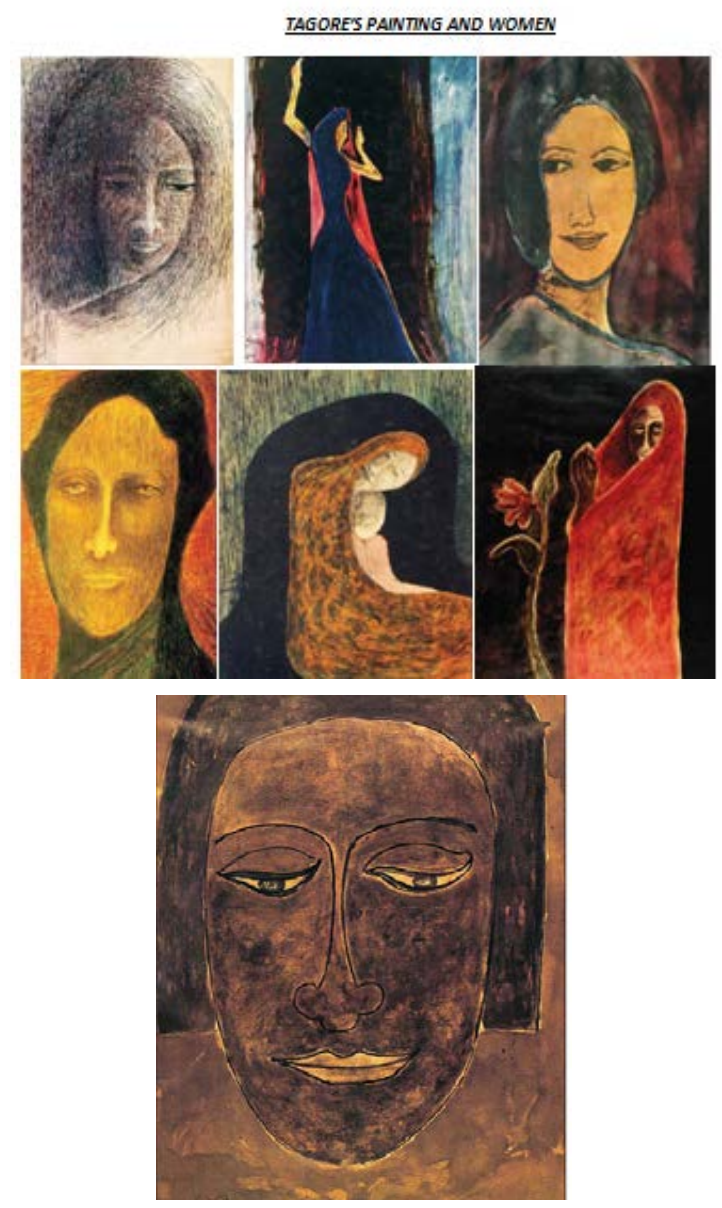
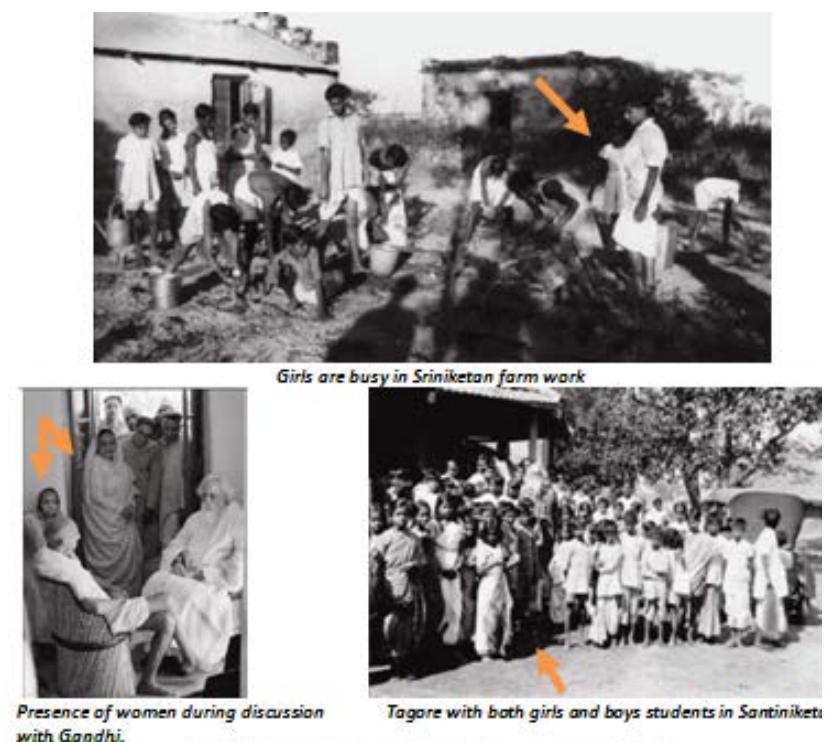

with.Gandhi.
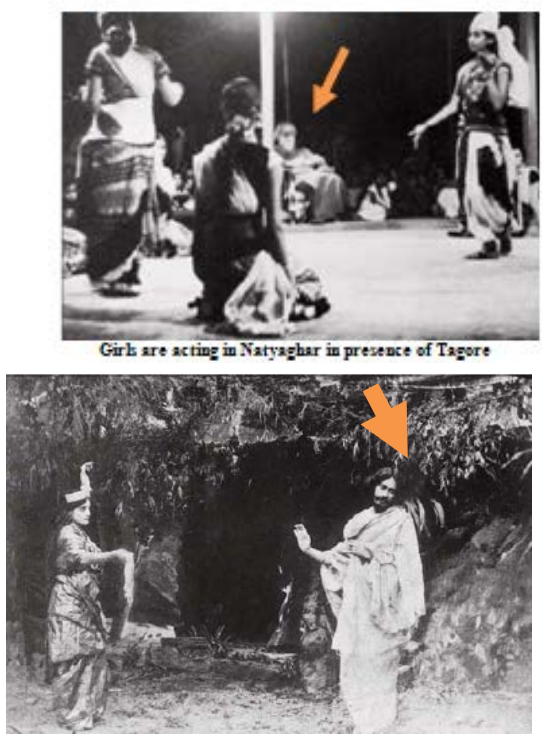

Tagore (left) and with Indira Devi (below) in Valmiki Pratibha

\section{CONCLUSION}

Through his novels, he was gifted to build new and vital female role models to enthuse a new generation of Bengali women. Later, by his act of admitting females into his Santiniketan School, he became an innovative pioneer in coeducation. Not content with imitating existing educational models, Tagore set out to create an substitute model of learning that was based on the education of the whole personality, whether male or female. It is hard to overestimate the social change that resulted through Rabindranath's writings and his support of women's participation in academic proceedings, sports, dance and creative expression. 


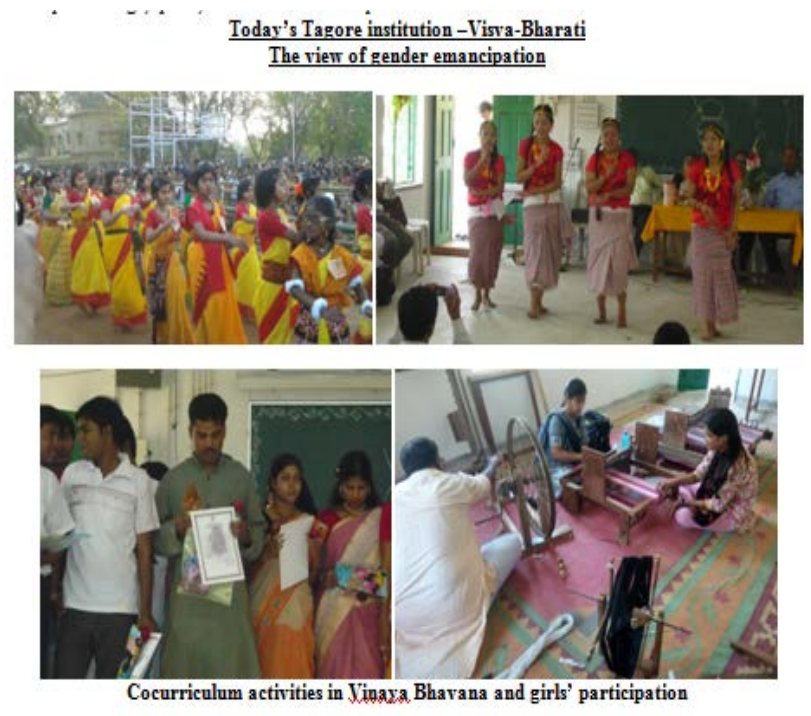

\section{REFERENCE}

[1] Ramandeep Kaur October 15, 2013. Portrayal of Women by Rabindranath Tagore http://www.mapsofindia.com/my-india/india/ portrayal-of-women-by-rabindranath-tagore

[2] Rabindranath Tagore: His Portrayal Of Women. Article paru dans Le Mauricien|7 août, 2013 - 16:00 | Par ROSHNI BANYMANDHUB http://www.lemauricien.com/article/rabindranath-tagore-his-portrayalwomen

[3] Rushiraj Bhatt The role of woman in Rabindranath Tagore's short Stories. The role of women in Tagore's literature.(articals international seminar on Tagore's literature in Meerut.2009. INDIAN JOURNAL OF APPLIED RESEARCH .Pp.11 Volume : 3 | Issue : 2 | February 2013 | ISSN - 2249-555X

\section{BIBLIOGRAPHY}

[1] Bardhan, Kalpana. Women, Outcastes, Peasants, and Rebels. Berkeley: Univ. of California Press, 1990.

[2] Dyson, Ketaki Kushari. I Won’t Let You Go. Newcastle Upon Tyne: Bloodaxe Books, 1991.

[3] Sadashiv Pawar, Dept. of English, Shri. A. B. College, Deogaon The Portrayal of Women and Social Oppression in Rabindranath Tagore"s ", The Postmaster" and „The Conclusion"

[4] Tagore, Rabindranath. "The Conclusion.” Rabindranath Tagore: An Anthology. Krishna Dutta and Andrew Robinson, edt. London: Picador, 1997. 268-287.

[5] Tagore, "A Poet"s School." Rabindranath Tagore: An Anthology. 248261.

[6] Tagore,"The Postmaster.” Stories from Tagore. Calcutta: Macmillan, 1958. 89-97.

[7] Thompson, Edwards. Rabindranath Tagore: His Life and Works. Calcutta: Association Press, 1921.

[8] Dr Rabindranath Tagore, Ssanchayita2. Kaiser Haq, The Philosophy of Rabindranath Tagore.3.

[9] Pathan, MD Feminism Reflected In Rabindranath Tagorees Plays:, Chitra"e, „Natirpuja" \&,,Chandalika".

[10] Prof Bharati Ray, New Woman in Rabindranath Tagore"s Short Stories: An Interrogation of Laboratory 